\title{
The board of directors in South Africa: its role in corporate strategic planning
}

\author{
J. Viljoen \\ Department of Business Administration, Rhodes University, Grahamstown
}

\begin{abstract}
There is a considerable degree of uncertainty regarding the precise role of the board of directors in corporate strategic planning. With reference to the South African Company Law and practice the objectives of this paper are (i) to isolate and categorize possible alternative relationships between top management and the board of directors in matters of corporate strategy; (ii) to identify the level at which the board should become involved in corporate strategy; (iii) to suggest which elements of strategy should be the legitimate concern of the board; (iv) to propose procedural guidelines which will facilitate optimal board involvement in corporate strategy. The author concludes that the board of directors, in terms of its mandate, should not only become involved in strategy evaluation but also in the formulation and implementation of strategic plans. This is particularly true within the context of the current socioeconomic and political environment in South Africa. The implications of this conclusion for the composition of the board and for the conducting of board affairs are discussed.
\end{abstract}

S. Afr. J. Bus. Mgmt. 1986, 17: $215-219$

Aansienlike onsekerheid heers aangaande die presiese funksie van die direksie ten opsigte van strategiese beplanning. Met betrekking tot Suid-Afrikaanse Maatskappyreg en -praktyk, stel hierdie werk dit ten doel om: (i) moontlike alternatiewe verwantskappe tussen bestuur en direksie betreffende maatskappystrategie te identifiseer en te klassifiseer; (ii) die toepaslike vlak waarop direksie in maatskappystrategie betrek behoort te word, te identifiseer; (iii) voor te stel watter elemente van strategie die belangstelling van die direksie regverdig; (iv) prosedureriglyne aan te bied ten einde optimale betrokkenheid van direksie in maatskappystrategie te bewerkstellig. Die outeur kom tot die slotsom dat die direksie, volgens sy mandaat, nie net in die evaluering van strategie betrokke behoort te raak nie, maar ook in die formulering en implementering van strategiese planne. Die implikasies hiervan vir die samestelling van die direksie en vir die uitoefening van direksie-aangeleenthede word daarna bespreek.

S.Afr. Tydskr. Bedryfst. 1986, 17: 215 - 219

\section{Introduction}

Traditionally, the board of directors only involves itself in the strategic planning process to the extent that it passively approves the plans of top management and, when necessary, hires and fires the chief executive officer (CEO). As a result many boards are captives of management until such time as a crisis arises which forces them to challenge managerial capabilities. Generally, boards are not suitably responsive to the strategic issues that face their respective companies.

In South Africa, as elsewhere in the world, rapidly escalating social, political, technological, and competitive pressures are demanding a drastic revision of the traditional role of the board of directors. Nowhere is change more necessary than in the field of strategic management. The challenge is to enhance the strategic performance of the CEO through the balanced involvement of a thoughtful and informed board of directors (Cabot, 1976:40). Accordingly, an effective board should: (i) insist on a unique, viable and durable corporate strategy from its management, (ii) review the strategy periodically to ensure its continuing appropriateness, (iii) where necessary, use the strategy as a reference point for board decisions, (iv) forge a partnership with management by sharing the risks associated with persuing the strategy (Andrews, 1980:30).

In this paper strategy is viewed as:

'the pattern of decisions in a company that (i) determines, shapes, and reveals its objectives, purposes, or goals; (ii) produces the principal policies and plans for achieving these goals; and (iii) defines the business the company intends to be in, the kind of economic and human organization it intends to be, and the nature of the economic and non economic contribution it intends to make to its shareholders, employees, customers, and communities' (Christensen, Andrews, Bower, Hammermesh \& Porter, 1982:93).

Whilst the basic functions of a board to guide, direct and control the company and to adequately manage its assets and affairs, may not imply a responsibility to formulate strategy, every board should at least play a more active role in reviewing strategy and in monitoring and controlling the process that produces strategy (Andrews, 1981a:17).

\section{The traditional strategic role of the board}

Businesses traditionally operate on the understanding that because management shoulders responsibility for implementing strategy, it should also formulate strategy. Board involvement in the process is negligible. Furthermore, many boards are dominated by directors who are also company 
employees (executive directors). There is a real danger that these directors may be so concerned with tactical decisions and the daily operational performance of the company, that they either fail to recognize and act on more important broader issues of strategy, or they approach these issues in an unduly subjective manner. In either case the frank and open discussion of strategic matters at board level is hampered. This problem is compounded by the fact that managers are regularly given powerful incentives, frequently of a financial nature, to concentrate their efforts on solving short-run operational problems (Banks \& Wheelright, 1979; Lauenstein, 1982:110). Thus, the lack of strategic input from traditional boards may not be adequately compensated for by a strategyorientated management team. Furthermore, many traditional boards are simply too burdened with administrative detail to become meaningfully involved in corporate strategy (Lauenstein, 1982:114). In fact there is evidence to suggest that the board's involvement in strategy often occurs only as a direct result of declining company performance owing to the inadequacy of the CEO and his top management team (Boulton, 1984:90; Lauenstein, 1982:110).

These traditional functions of the board are undoubtedly inadequate for the requirements of businesses operating in today's competitive local or foreign markets and striving to survive in South Africa's volatile socio-political environment. In future, South African boards are likely to be held responsible for much more than the simple monitoring of a company's economic performance. A greater awareness of the role and importance of business in society will bring about the demand that boards be charged with the long-term sensitivity and responsiveness of the company to both its economic environment and to society in general (Tashakori \& Boulton, 1983).

\section{The level of board involvement in strategy}

The board of directors may involve itself with corporate strategy at any one or more of three levels, as shown in Figure 1.

Deciding, in terms of the duties, functions and responsibilities of directors, which level of board involvement in strategy is most desirable is no easy task. In fact, in terms of a company's Articles of Association, directors may be given the right to delegate to management such of their powers and authority as they think fit including, presumably, the authority to take command of whatever elements of the company's planning and control functions they consider appropriate (The Companies Act, 1973, Table A, Section 62:215). Although this provision normally effects operational or technical activities it legally entitles the board to cast off many functions of a strategic nature.

Current practice would appear to indicate that, at best, boards limit their participation in strategy to issues of implementation (level 2) and evaluation (level 3) only, though there is by no means consensus on this matter (Felton, 1979; Tashakori \& Boulton, 1983). Furthermore, most evaluation of strategy takes place predominantly at a short-term financial level rather than at a more exhaustive strategic level. As long as short-term financial results appear satisfactory little attention is paid to the evaluation of more enduring issues such as: (i) the continuing applicability of the mission of the company; (ii) the degree of synergy between past, present and planned investment; (iii) the viability of alternative strategies in the light of changing socio-economic, technological and political conditions; and (iv) company performance in terms of non-financial criteria, such as innovation, social responsibility, staff development and organizational culture. In reality the fact is that a comprehensive strategy evaluation of this nature would not only require a detailed knowledge of all facets of the strategy of the company, but also a thorough awareness of the process that produced that strategy - that is, how the strategy was developed and precisely why it is important to the success of the company. In short, a thorough evaluation of company performance (strategy level 3) requires a full understanding of all levels of strategic decision making - including strategy formulation. Accordingly, it is difficult to justify partial board involvement in corporate strategy.

\section{The degree of board involvement in strategy}

Quite apart from the level at which the board becomes involved in strategy, there are essentially five different degrees of board involvement in strategic management. These are portrayed in Figure 2.

In terms of Figure 2 the volatile nature of the South African business environment requires boards to be more active in the field of strategy and to act as catalysts without impairing the integrity of management. However, many CEO's and board members alike try to de-emphasize the board's strategic role because both feel that directors, particularly outside (nonexecutive) directors, are unqualified to deal with such issues. In reality both are doing the company a disfavour. Judgement in matters of strategy is not linked directly to the degree of involvement in a company's operational activities and it is precisely because the board is, or should be, removed from such day-to-day operational activities that it can play such a useful role as a catalyst for strategic management.

\section{The managementboard interface and corporate strategy}

The involvement of the board in corporate strategy, together with the involvement of management, typically leads to one of four strategic management styles, (Wheelen \& Hunger, 1983:62-63) as illustrated in Figure 3.

Although partnership management would appear to

Level 1: Strateoy formulation

- Determining the mission of the business

- Formulating long-run objectlves

- Developing tactical plans to achieve objectives

Level 2: Strategy implementation

- Allocating resources and skills in accordance with level 1 decisions

Lenel 3: Strategy evaluation

- Monitoring the results of the resource allocation process accomplished at level 2

Figure 1 Alternative levels of board involvement in strategy. 


\begin{tabular}{|cccc|}
\hline Low & Board Involvement in Strategic Management & High \\
\hline Zero & Rubber Stamp & $\begin{array}{c}\text { Nominal } \\
\text { Participation }\end{array}$ & Active \\
Participation & Catalyst
\end{tabular}

\section{Zoro involvement}

These boards have virtually no involvement in corporate strategic affairs. They know little, if anything, about strategy in general nor about the strategy of their organization in particular.

\section{Rubber stamp}

These boards allow management to make all strategic decisions and vote as the CEO recommends without understanding the implications of what they are doing.

\section{Nominal participation}

These boards review some selected strategic issues, either at their own request or at the request of management.

\section{Active participation}

These boards review and make final decisions on matters of a strategic nature. They usually have active board committees and conduct regular financial and management audits.

\section{Catalyst}

These boards play a leading role in the development and evaluation of corporate strategy. They have an active strategy committee.

Figure 2 Degrees of board involvement in strategic management (Adapted from: Wheelen \& Hunger, 1983:49).
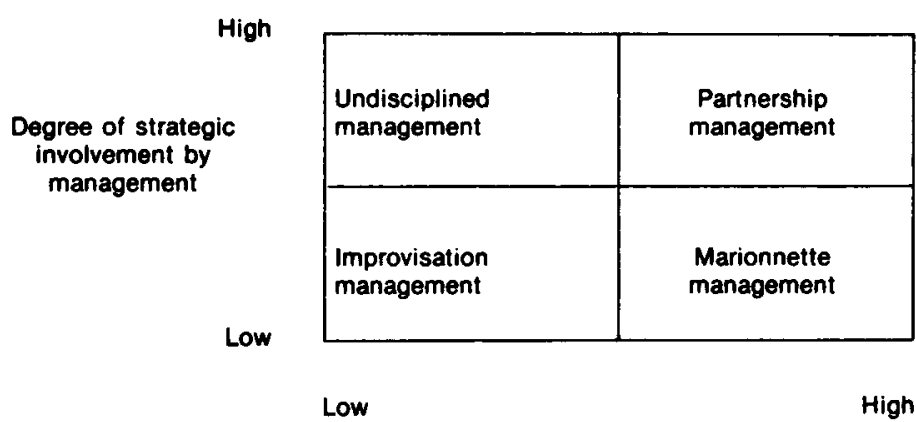

Degree of strategic involvement by the board of directors

Improvisation management occurs where the board performs its directing and controlling function passively while at the same time management is operationally orientated. As a result the company has a very short planning horizon and management's lask becomes one of reacting, almost impulsively, to whatever current influences it perceives as being important. There is no strategic management being practiced here.

Undisciplined management occurs when the board of directors is passive but top management is highly involved in strategy. Here the board's role is predominantly one of rubber stamping, while the CEO dominates the organization and its strategic decisions.

Marionnette management is probably the rarest form of strategic management style. It occurs when the board dominates strategic decision making leaving management the task of ensuring the organization's operating efficiency. Such a situation may arise where the board is composed of key shareholders, and/or where the CEO is new and requires considerable board assistance in order to perform his task effectively.

Partnership management occurs where both the board and top management are deeply involved in corporate strategy. They work together in establishing and reviewing key strategic issues such as the corporate mission, objectives and policies. The board usually has many active committees including a strategy committee.

Figure 3 Board and management involvement in strategy.

represent the ideal situation, it is seldom found (Brady \& Helmich, 1984:37). Top management, together with board members, often feels that such a style represents an encroachment by the board onto management turf and as such is unacceptable. This attitude is supported by the decidedly nonstrategic nature of the statutory duties of directors as outlined in sections 208-251 and in Table A of The Companies Act, 1973. These duties, in essence, require only that directors manage the affairs of the company, determine the payment of interim dividends, recommend payment of final dividends for approval at the annual general meeting, consider the need to set aside reserves out of profit, and prescribe the manner and form in which share certificates are to be issued. In fact, it is the common law duties of directors which come closest to encouraging the board to perform a strategic role. By common law the fiduciary relationship which exists between the company and its directors requires each director to exercise his power solely in the interests of and for the benefit of the company. This may be interpreted as obligating the director to perform a strategic role by authorizing him to take actions of any nature which will enhance the probability of the survival and profitability of the company, both in the short 
and long term. Unless directors, particularly outside or parttime directors, view their task in a broader perspective, the likelihood of ever achieving partnership management is remote indeed.

\section{Improving the boand's involvement in corporate strategy}

In the event that a board's concern with corporate strategy is lacking, it may improve its contribution by ensuring that it competently performs the following functions.

- Advise management on the establishment and revision of the broad definition of purpose and goals of the company - the aim, scope and mission of the business. Outside or part-time directors, who by virtue of their positions are less involved in the melee of business operations, can play a particularly useful role here.

- Coax management into focusing more attention on the longrun objectives of the company within the context of anticipated social, technological, political, economic and competitive trends. Only a thorough understanding of the strategic impact of these environmental trends can destroy the prevalent myth that superior business performance is predominantly due to managerial proficiency, whilst poor business performance is predominantly the result of an unfavourable environment.

- Assess the viability of the strategies and tactics to be used in achieving objectives and to recommend alternatives as necessary.

- Monitor the resource allocation activities of management in the light of the company's objectives and with regard to current and anticipated environmental trends.

- Ensure that the company's strategy is used as the fundamental reference point for all board decisions.

- Insist on evidence that management at least has a process for formulating, implementing and evaluating strategy.

In order to assist the board in fulfilling these functions the following procedural guidelines should be implemented:

- A Corporate Strategy Committee should be established to ensure that the board's strategic functions are fully and properly discharged. In terms of the Articles of Association (The Companies Act, 1973, Table A, Section 80:218), the board is entitled to authorize the appointment of such a committee and to allocate to it whatever power and duties the board sees fit. The Strategy Committee should report regularly on its activities and should be charged with ensuring that the board is always fully informed on matters of strategic importance facing the company (Andrews, 1981b:18).

- All board members, particularly outside directors, should be made fully au fait with the organization's strategy, the influences that led to its development and the reasons why it is critical to the competitive success of the organization (Lewis, 1974:76). Outside directors, unlike executive directors, have not undertaken any special obligation with regard to the management of the company. They are not bound to give continuous attention to the affairs of the company and their duties are of an intermittent nature. Such directors can easily loose touch with the managerial realities of the company and are consequently unable to perform their duties and functions adequately. However, if they are kept informed, without being burdened with masses of operational information, they can make a major contribution towards the quality of board decisions and activities, especially in a wider, strategic context.

- Full-scale strategy review sessions should be conducted periodically by the entire board. At these sessions it is particularly useful for directors to act as a sounding board for the CEO and his strategic management team (Wommack, 1979:49).

- Where feasible, and where the fiduciary duties of directors will not be comprised, a sufficient number of external directors, including interlocking directorships, should be established. This will enable the company to acquire useful information about uncertain environmental conditions and to bring to the board objective expertise about the organization's strategy.

The use of outside directors and, more particularly, interlocking directorships should be approached with caution in view of the fact that such directors must beware of breach of fiduciary duty. Although a director of one company is not prohibited from serving as a director of another company, even if that company is a competitor of the first, he will be placed in an almost impossible position if he cannot honestly act in the best interests of both companies. In terms of section 215 (1)(b) of The Companies Act (1973:94) every director must disclose, in the appropriate company register, the name and registered office of every other company of which he is a director. This provision effectively ensures that directors cannot conceal potential conflict of interest and subsequent breach of fiduciary duty.

- An executive committee should be formed for the purpose of dealing with routine matters confronting the board, thus making more time available to allow full discussion of strategic matters.

- Long service on the board should be encouraged in order to develop good rapport amongst members and better appreciation of the long-term strategic issues facing the company. At the same time, the board must prevent stagnation arising through long service by a core of conservative directors. Such a problem is usually overcome through the adoption of section 66 of the Articles of Association (The Companies Act, 1973, Table A: 215) which makes provision for directors to retire in rotation (one third of the board at every annual general meeting) and subsequently to offer themselves for re-election if they so wish. Also, The Companies Act (1973, Section 210(1):92) stipulates that the appointment of each director be voted on individually at a general meeting. As a result it is within the power of the shareholders of the company to ensure that every director, as an individual and regardless of his length of service, is both capable and fully motivated to perform his function adequately.

\section{Conclusion}

As the South African corporate environment becomes more complex and dynamic, pressure for greater board involvement in strategy will grow. However, change will not come easily. Outside directors are often insufficiently informed regarding company affairs and hence prefer to leave matters of strategy, if any, to 'better-qualified' executive directors. Many boards are heavily burdened with administrative duties and resist the idea of using properly constituted executive committees to relieve this burden. Furthermore, the board is the decisionmaking unit farthest removed from the operating activities of the company and hence must ensure the existence of a rapid and effective information system before it can responsibly deal with matters of strategy. This will become increasingly difficult with the continuing trend toward massive concentric and conglomerate diversification and the development of multi- 
divisional organization structures. These problems are exacerbated by the non-strategic nature of the statutory duties of directors in South Africa.

\section{References}

Andrews, K.R. 1980. Directors' Responsibility for Corporate Strategy. Harv. Bus. Rev., November-December, 30-42.

Andrews, K.R. 1981a. Corporate Strategy as a Vital Function of the Board. Harv. Bus. Rev., November-December, $174-184$.

Andrews, K.R. 1981b. Replaying The Boards Role in Formulating Strategy. Harv. Bus. Rev., May-June, 18-26.

Banks, R.L. \& Wheelright, S.C. 1979. Operations versus Strategy: Trading Tomorrow for Today. Harv. Bus. Rev., May - June, $112-120$.

Boulton, W.R. 1984. The Board of Directors: Beware of Those Triggers That Case Board Change. J. Bus. Strat,, vol. 5, $84-92$.

Brady, G.F. \& Helmich, D.L. 1984. Leadership Style in the Boardroom. Directors and Boards, vol. 1, 37.
Cabot, L.W. 1976. Louis W Cabot on an Effective Board. Harv. Bus. Rev., September - October, 40-183.

Christensen, C.R., Andrews, K.R., Bower, J.L., Hammermesh, R.G. \& Porter, M.E. 1982. Business Policy: Text and Cases. Sth Edition. Homewood Illinois: Richard D Irwin Inc., 838p.

Felton, M.S. 1979. The Case of The Board and The Strategic Process. Harv. Bus. Rev., July - August, 20-36.

Lauenstein, M. 1982. Handling the Key Issues. J. Bus. Strat., vol. $2,110-114$.

Lauenstein, M. 1984. The Strategy Audit. J. Bus. Strat., vol. 4, $87-91$.

Lewis, R.F. 1974. Choosing and Using Outside Directors. Harv. Bus. Rev., July - August, 70-78.

South African Companies Act, No 61 of 1973, as amended.

Tashakori, A. \& Boulton, W.R. 1983. A Look at The Board's Role in Planning. J. Bus. Strat., vol. 3, 64-70.

Wheelen, T.L. \& Hunger, J.D. 1983. Strategic Management and Business Policy. Reading, Massachusetts: Addison-Wesley, 978p.

Wommack, W.W. 1979. The Boards Most Important Function. Harv. Bus. Rev., September-October, 48-62. 